\title{
COVID-19 Health Communication: Key Moderators of Message Framing*
}

\section{Ковід-19 Комунікація з питань здоров'я: ключові модератори формування мовленнєвих повідомлень **}

\author{
Dina Abdel Salam El-Dakhs ${ }^{1}$ \\ Ph.D. in Linguistics, \\ Associate Professor
}

\author{
Діна Абдель Салам Ель-Да' \\ доктор філософії (Ph.D.) \\ у галузі лінгвістики
}

\author{
E-mail: ddakhs@psu.edu.sa \\ https://orcid.org/0000-0003-2943-987X \\ Researcher ID: M-9425-2017 \\ Scopus Author ID: 51763574200
}

Jeanette Altarriba ${ }^{2}$

Professor in Psychology
Жанетт Альтарріба ${ }^{2}$

професор у галузі психології

E-mail: jaltarriba@albany.edu https://orcid.org/0000-0002-9510-101X

Researcher ID: Z-4975-2019

Scopus Author ID: 7004440368

\section{Ahmed Masrai ${ }^{3}$ \\ Ph.D. in Linguistics,}

Associate Professor in Linguistics
Ахмед Масраi ${ }^{3}$

доктор філософії (Ph.D.)

у галузі лінгвістики

Email: a.masrai@hotmail.com https://orcid.org/0000-0002-6778-5952

Researcher ID: U-5427-2019

Scopus Author ID: 56674700900

* Research project through the Applied Linguistics Research Lab grant IBRP-CH-2020-6-1

** Дослідницький проект виконаний у рамках гранда науково-дослідницької лабораторії прикладної лінгвістики IBRP-CH-2020-6-1 
COVID-19 Health Communication: Key Moderators of Message...

${ }^{1}$ Prince Sultan University,

College of Humanities

P.O.Box No. 66833 Rafha Str.,

Riyadh, Saudi Arabia, 11586

${ }^{2}$ University at Albany,

State University of New York

1400 Washington Avenue, Albany,

New York, USA, 12222

${ }^{3}$ King Abdulaziz

Military Academy

Riyadh, Saudi Arabia, 11538
${ }^{1}$ Університет Принцฺа Султана, Гуманітарний коледж

Р.O.Вох, вул. Рафха, 66833,

Рейад, Саудівська Аравія, 11586

${ }^{2}$ Університет в Олбані, Державний університет Нью-Йорка

1400 Вашингтон Авеню, Олбані, Нью-Йорк, США, 12222

${ }^{3}$ Військова Академія

імені Короля Абдель Азіза

Рейад, Саудівська Аравія, 11538

Original manuscript received February, 01, 2021

Revised manuscript accepted March, 12, 2021

\begin{abstract}
Objective. Earlier studies on message framing in the health sector have often focused on the effectiveness of framing in terms of behaviour change and decision making. Much less attention has been paid to the influence of message framing on the emotional responses of the recipients. This neglected aspect is extremely important particularly at times of crises because health care professionals wish to persuade the public to comply with their health advice without causing unnecessary anxiety. The current study examined the effect of message framing on the affect of Arabicspeaking Saudi nationals and residents of Saudi Arabia during the COVID-19 lockdown. The effect of message outcome/severity and the recipients' age/levels of depression and anxiety was also investigated.
\end{abstract}

Materials \& methods. A total of 348 participants of three age groups completed the Beck Depression Inventory (Beck et al., 1996) and the State-Trait Anxiety Inventory (Spielberger et al., 1983), and rated the positivity of 48 COVID-19 health messages of different framing along a 6-point Likert scale.

Results. The results showed a strong effect of message framing and severity and the recipients' age on the recipients' emotional responses. A limited influence for message outcome was also noted.

Conclusions. It is recommended to use gain-framed health messages to the public in order to avoid anxiety and maintain their positive affect. This is particularly recommended with younger adults whose affect gets negatively impacted by lossframed messages quite easily. Loss-framed messages are recommended for in severe situations that have desirable outcomes.

Key words: health communication, public's affect, anxiety, message framing, age, message outcome, COVID-19. 


\section{Introduction}

Message framing refers to "the persuasive strategy either to highlight benefits and rewards from compliance with the message advocacy or to emphasize the costs and punishments associated with non-compliance» (Shen \& Kollar, 2015: 626). Message framing occupies a central position in health communication (e.g., Bai et al., 2019; Wansink \& Pope, 2014) because health professionals and institutions aim to have patients/caregivers/the public comply with their messages for their personal benefit as well as for societal good. In the health domain, messages can be framed in two different forms, namely, gain-framed messages which highlight the benefits (gains) of adopting a particular healthy behaviour and loss-framed messages which emphasize the cost (losses) of not adopting a healthy behaviour (Rothman \& Salovey, 1997). As shown in Table 1, gain-framed messages highlight how adopting a particular healthy behaviour (i.e., «frequent exercising») can lead to attaining a desirable outcome (i.e., «good respiratory functions») or the avoidance of an undesirable outcome (i.e., «bad respiratory functions»), while loss-framed messages emphasize that not adopting a healthy behaviour (i.e., «infrequent exercising») can reduce the possibility of attaining desirable outcomes or lead to undesirable outcomes (Liu et al., 2019).

Table 1. Examples of message framing and outcome types (adopted from Liu et al., 2019)

\begin{tabular}{lll}
\hline $\begin{array}{l}\text { Message } \\
\text { Type }\end{array}$ & Outcome Type & Example \\
\hline Gain & Attain desirable & Frequent exercising can lead to good respiratory functions \\
& Avoid undesirable & Frequent exercising can prevent bad respiratory functions \\
Loss & Avoid desirable & Infrequent exercising can hinder good respiratory functions \\
& Attain undesirable & Infrequent exercising can lead to bad respiratory functions \\
\hline
\end{tabular}

The different construction or phrasing of health messages has a strong effect on the desire for behaviour change (Rothman \& Salovey, 1997) and can evoke different emotional responses (Mikels et al., 2016). These effects can vary when controlling for the age of the participants, since aging tends to bring a shift toward positivity in emotional experience (Carstensen, Mikels \& Mather, 2006). In fact, 
message framing has different effects on the health behaviours of older versus younger adults (Notthoff \& Carstensen, 2014) and can influence information search and memory for health decisions differentially among younger and older adults (Löckenhoff \& Carstensen, 2007). However, little is known about how the phrasing of health messages can impact the affective responses of the participants (Liu et al., 2019; Mikels et al., 2016). In other words, can subtle differences in the expression of health messages increase the positive or negative reactions of the message receivers? Are there recommended practices for how to phrase messages in a way that can lead to positive affective responses and thus reduce the potential anxiety of the recipients? Answering these questions is important practically and theoretically. On the practical front, a better understanding of the effect of message framing on people's emotional responses is needed to tailor health messages in a more appropriate way (Liu et al., 2019). On the theoretical front, understanding how the linguistic expression of information can have differential emotional effects on the message recipients is important to solving a broad range of problems (Stine-Morrow \& Radvansky, 2017).

The current study seeks to advance our knowledge on the influence that message framing has on the affective responses of Arabic-speaking Saudi nationals and residents during the COVID-19 lockdown, which is a time characterized by an intensive exposure to several health messages with respect to relevant precautionary and preventative measures. The focus is on the affective responses of the recipients to COVID-19 health advice during the lockdown imposed in Saudi Arabia. In addition to the influence of message framing (gain/loss), the current study aims to examine the effect of a number of potential moderating factors, including message outcome (desirable/undesirable), the severity of the precautionary or preventative measure (less severe/more severe), and the recipient's age (old/middle/young) and psychological state (anxiety and depression).

The current study has both theoretical and practical values. On the theoretical front, the findings will inform models of message framing in terms of their potential affective influences on recipients when various important moderators of the message are controlled. These findings will be particularly enriching because the focus of the current study will be on Arabic, a language that is extremely under-represented in the health communication literature. On the practical front, the current study 
will have direct implications on health communication since it will provide evidence-based recommendations on how to best phrase health messages with regards to preventative measures at times of crises. The recommendations will be particularly relevant to Saudi Arabia since the study participants will be recruited among Saudi nationals and residents.

\section{Literature Review}

From the perspective of 'prospect theory', health message framing in the form of gain-framed messages, which highlight the benefits of avoiding a risky behavior, versus loss-framed messages, which emphasize the costs of engaging in a risky behavior, differentially affects behavioral outcomes (Rothman \& Salovey, 1997; Tversky \& Kahneman, 1981). According to the proponents of this theory, gain-framed messages are more effective in motivating disease prevention behaviours (e.g., sun protection) while loss-framed messages are more effective for early disease detection behaviours (e.g., mammography) (Mays \& Evans, 2017). Evidence from meta-analyses supports this perspective but emphasizes that the framing effects are variable for specific behaviours within disease prevention and detection (Gallagher \& Updegraff, 2012).

In order to quantify the effect of health message framing on behavioural change, a number of studies have been conducted. For example, Toll et al. (2007) tested the hypothesis that gain-framed messages will be more persuasive than loss-framed messages when attempting to encourage smoking cessation. To this end, 258 Englishspeaking participants residing in the USA were assigned to a gainframed condition or to a loss-framed condition. The two conditions received a factually equivalent video and printed messages urging them to stop smoking, but the message framing was different. The results did not reveal any significant differences between the two groups with respect to the intent-to-treat analysis. However, a significantly higher proportion of participants were continuously abstinent in the gain-framed condition as compared to the loss-framed condition. These findings lend support to the message framing hypothesis since the gain-framed messages appeared to be more persuasive than loss-framed messages in promoting early success in smoking cessation. Likewise, Balbo (2010) exposed English-speaking women residing in the USA $(N=209)$ to a pamphlet promoting Pap tests in an online experiment. The pamphlet was either gain-framed or loss-framed and emphasized the prevention or 
detection function of the Pap. As hypothesized, the fit between framing and function (i.e., gain-prevention and loss-detection) resulted in higher intention to follow the recommendation. Similarly, Updegraff et al. (2015) examined how gain- and loss-framed informational videos about oral health influence self-reported flossing behaviour over a six-month period. A total of 855 American adults from varied age and ethnic groups were randomized to gain-framed online video, loss-framed online video and control groups. Examining the self-reported flossing at two and six months revealed that the participants who watched a framed video had significantly greater likelihood of flossing at recommended levels than the control group, particularly when the gain- or loss-frame matched the recipient's beliefs about their health risks outcomes.

A number of studies have attempted to look beyond the prevention-detection dichotomy in order to discover the key moderators that influence the health message framing effect (e.g., Latimer, Salovey \& Rothman, 2007). An important moderator in this regard was aging. For example, Shamaskin, Mikels, and Reed (2010) examined the impressions, and memory for positively and negatively framed health care messages that were presented in pamphlets to 25 older adults and 24 younger adults. Both groups of participants were English-speaking residing in New York, USA. The results showed that older adults relative to younger adults rated positive pamphlets as significantly more informative than negative pamphlets and remembered a higher proportion of positive to negative messages. Additionally, older adults misremembered negative messages to be positive. These findings lent support to the age-related positive effect. Similarly concerned with aging, Mikels et al. (2016) measured the subjective and physiological affective responses of 31 older and 31 younger English-speaking adults to gain- and loss-framed exercise promotion messages. Relative to younger adults, older adults exhibited greater positive reactivity to loss-framed messages. This finding suggested that the age of the message recipient is a moderator of the health message framing effect. In the same vein, Liu et al. (2019) examined the emotional responses evoked by health message framing among 106 older and 132 younger adults who were native speakers of English and residents of the USA. Relative to younger adults, older adults showed less negative reaction to loss-framed messages and to messages that described undesirable outcomes. This result lent further support to the hypothesis that 
older adults are more motivated by positive affect in comparison to younger adults.

In addition to the age variable, other researchers have recently attempted to explore the influence of other moderators on health message framing. For example, Shen and Kollar (2015) employed a 2 (frame: gain vs. loss) X 2 (evaluative input: high vs. low) X 3 (target behaviour: sunscreen, self-exam, and indoor tanning) quasi-experimental design to test the influence of evaluative input on the message framing effect. The participants were 452 English-speaking undergraduates in an American university. The results showed that effectiveness of a frame is a function of its evaluative input. While the gain frame is more effective for prevention behaviour, the loss frame is more effective for detection behavior. No evidence was found, however, for a moderating framing effect with respect to proscriptive vs. prescriptive behaviours. Data also suggested that dispositional motivations can be a moderator of message framing effect but might be contingent upon level of evaluative input and type of behaviour. Similarly, Suka, Yamauchi, and Yanagisawa (2018) used six depression help-seeking messages that were prepared with three frames (neutral, loss and gain framed) X 2 formats (formatted and unformatted) in order to examine the responses of Japanese adults to differently framed and formatted persuasive messages in the context of developing depression help-seeking messages. The results showed that the loss-framed messages more strongly induced negative emotions (surprise, fear, sadness and anxiety) while the gain-framed messages more strongly induced positive emotions (happiness). Interestingly, the message formatting in accordance with the Centres for Disease Control and Prevention Clear Communication Index enhanced the emotional responses and increased the likelihood that the messages will be read.

Three other important variables that were recently examined are the communicative mode, the behavioural function, and risk prime. Elbert and Ots (2018) explored the role of communication mode in interaction with message framing. In their study, 258 Dutch participants were exposed to either an auditory or a written health message concerning fruit and vegetable intake, with either gain- or loss-framed messages. The results revealed a significant interaction between message framing and communication mode. An auditory message resulted in a higher intention to consume fruits and vegetables than a written message in case of gain-framed messages. This pattern was most notable among 
the participants with lower fruit and vegetable intake. In the same vein, Bruijn de (2019) investigated the interaction effects of message framing, behavioural function, and risk priming on mouth rinse use and intentions among Dutch adults $(N=549)$. The results demonstrated a significant interaction between message frame and behavioural function in the choice of mouth rinse products. A two-week follow-up revealed a significant interaction effect for message frame and risk prime on the mouth rinse behaviour.

Based on the literature review, it is clear that exploring the moderators of the health message framing effect is a recent research direction that is still in its infancy. This is an area that calls for further research for conceptual and procedural development. It must also be clear that the few studies that have been conducted in this direction are dominated by focus on the English language and English-speaking participants. Only three studies (namely, Bruijn de, 2019; Elbert \& Ots, 2018; Suka, Yamauchi \& Yanagisawa, 2018) have attempted to examine moderating effects in German and Japanese. No earlier research was conducted in the Arabic language although the population of the Arab World exceeds 400 million (Statista, 2020). The current study aims to fill these two clear gaps in the literature through examining the moderating effects of message outcome (desirable vs. undesirable), aging (older vs. middle-aged vs. younger), severity of the measure (less severe vs. more severe), and psychological status (depression and anxiety) on the health message framing effect (gain vs. loss). The current study examines these potential moderators during the COVID-19 lockdown among Arabicspeaking Saudis and residents of Saudi Arabia. More specifically, the current study addresses the following research questions:

RQ1: To what extent do message framing, message outcome and the severity of messages influence the affective responses of the recipients of health messages during the COVID-19 pandemic?

RQ2: To what extent does age interact with the influence of message framing, message outcome and the severity of messages on the affective responses of the recipients of health messages?

RQ3: Is there a relationship between the recipients' anxiety and depression, and message framing, message outcome, and the severity of messages? 


\section{Methods}

\section{Participants}

Three groups of participants took part in the study. Group one represents young adults $(N=212$, Males $=32$; Females $=180)$ who range in age from 18 to $30(M=22.39, S D=3.39)$. Group two represents middle-aged participants $(N=95$, Males $=25$; Female $=70)$, who range in age from 31 to $45(M=37.57, \mathrm{SD}=4.32)$. Group three represents older participants $(N=41$, Males $=18$; Females $=23)$ who range in age from 46 to $80(M=54.17, \mathrm{SD}=6.48)$. All the participants were native speakers of the Arabic language and were either nationals or residents of Saudi Arabia at the time of COVID-19 lockdown (March May 2020). They were recruited through email messages and social media. They all participated in the study on a voluntary basis.

\section{Materials}

Two types of sentences were composed for the purpose of the current study. First, we created 12 sets of sentences, each of which consisted of 4 sentences following this pattern:

(a) Gain-framed + desirable outcome:

Wearing the face mask outside your home makes you enjoy good health.

(b) Gain-framed + undesirable outcome:

Wearing the face mask outside your home protects you from suffering from the disease.

(c) Loss-framed + describable outcome:

Not wearing the face mask outside your home deprives from enjoying good health.

(d) Loss-framed + undesirable outcome:

Not wearing the face mask outside your home exposes you to suffering from the virus.

The sentences in every set were of similar lengths - the difference could be a maximum of two words. Six of the sets included more severe measures (e.g., Avoiding holding gatherings for condolences in case of deaths maintains the health of those around you.) while the remaining six sets included less severe measures (e.g., Following health guidelines protects your safety and the safety of your family.) 
We later assigned one sentence of each set to one of four versions of the study surveys. This counter-balancing of sentences aimed to ensure that the participants see only one sentence of every set and thus do not guess the underlying message framing principles. Second, we composed 18 sentences to act as fillers which varied in their framing and were used in the 4 versions of the study survey.

\section{Instrument}

As explained earlier, we created four versions of the study survey and administered them through Google forms. The surveys were written in the Arabic language because our target participants were Arabs, whether Saudi nationals or Arab residents in Saudi Arabia. All surveys consisted of five sections. The first section of the survey included a consent form. In the consent form, the researchers provided a brief explanation of the study purpose and procedure in addition to all other necessary information as per standard ethical standards, such as highlighting the voluntary nature of participation and the participants' right to withdraw at any point without having to provide justification. Only after the participants granted their consent, they could move to the remaining sections of the survey. The three following sections included a consent form, a biographical information form (including the participant's age, gender, nationality, latest educational qualification and the Saudi city of residence), a translated version of the Beck Depression Inventory (BDI-II; Beck, Steer \& Brown, 1996) and a translated version of the «state» portion of the State-trait Anxiety Inventory (SAI; Spielberger et al., 1983). The English version of the two tests can be found in Appendices A and B, respectively. We used these two tests because they have been validated as measures of depression and anxiety. The last section of the survey included 30 health messages related to the typical COVID-19 preventative and precautionary measures (e.g., Keeping a safe distance between yourself and others increases your chances of safety.). The participants were required to read each message and rate it on a 1-6 Likert scale (i.e., 3+ extremely positive; 2+ moderately positive; $1+$ little positive; 1- little negative; 2- moderately negative; 3 - extremely negative) to express the emotions that these messages evoked for them. The 30 sentences consisted of 18 filler sentences and 12 target sentences. It is worth noting that this study was conducted 
after receiving an ethical clearance from the Institutional Review Board of Prince Sultan University PSU IRB-2020-06-0046.

\section{Data Collection}

As noted earlier, the surveys were prepared using google forms. The links were shared with different groups of participants through email messages and social media platforms. The four versions were completed by different numbers of participants, ranging from 81 to 96 participants $(M=88.5)$. Please, note that our dataset is available on the data repository «Mendeley Data» (2021).

\section{Results}

\section{Message Framing Results}

Message framing ratings were analyzed using various measures. First, descriptive statistics were conducted to obtain a general view of the data. Second, multiple mixed model analysis of variance (repeated measures ANOVA) was used, in which within-subjects factors involved message frames and message outcomes, and age (young, middle-aged, old) was a between-subjects factor. Message frame was classified into three types: (MF1) gain, loss, (MF2) gain-less severe, gain-more severe; and (MF3) loss-less severe, loss-more severe. Message frame also included desirable and undesirable outcomes for each variable.

Descriptive statistics, summarized in Table 2, show that the participants responded generally more positively to gain messages than to loss messages. In addition, the participants appeared to be more positive to gain messages that are less severe than more severe but were less positive to loss messages that are less severe than more severe. Similar responses were also observed with desirable and undesirable outcomes in both conditions.

In order to examine the data more thoroughly, analyses of repeated measures (ANOVA) were conducted. The results indicate a main effect of frame, where the participants responded significantly more positively to gain-framed messages $(M=5.43, S D=.78)$ than to lossframed messages $(M=5.02, S D=1.22), F(1,347)=37.71, p<.001$, $\left.\eta_{\mathrm{p}}^{2}=.099\right)$. No emerging main effect was found for gain-framed messages outcome $\left(F(1,347)=3.66, p=.057, \eta_{\mathrm{p}}{ }^{2}=.010\right)$, but a more 
COVID-19 Health Communication: Key Moderators of Message...

positive significant inclination has emerged for loss-framed messages with undesirable outcome $\left(F(1,347)=9.01, p=.003, \eta_{p}^{2}=.025\right)$. However, a main effect of message frame severity (less and more severe) also emerged. The participants were significantly more positive to gain messages that are less severe $(F(1,347)=7.18, p=.008$, $\left.\eta_{\mathrm{p}}^{2}=.020\right)$ and loss messages that are more severe $(F(1,347)=11.69$, $\left.p=.001, \eta_{\mathrm{p}}^{2}=.033\right)$.

Table 2. Descriptive statistics of message-frame types

\begin{tabular}{llccccc}
\hline Message frame type & & $\boldsymbol{N}$ & Min & Max & M & $\boldsymbol{S D}$ \\
\hline MF1 & Gain & 348 & 1 & 6 & 5.43 & .78 \\
MF2 & Loss & 348 & 1 & 6 & 5.02 & 1.22 \\
& Gain LS & 348 & 1 & 6 & 5.47 & .81 \\
MF3 & Loss LS & 348 & 1 & 6 & 4.92 & 1.32 \\
& Gain MS & 348 & 1 & 6 & 5.36 & .92 \\
MF1 & Loss MS & 348 & 1 & 6 & 5.09 & 1.28 \\
& Gain D & 348 & 1 & 6 & 5.45 & .79 \\
& Gain UD & 348 & 1 & 6 & 5.39 & .89 \\
MF2 & Loss D & 348 & 1 & 6 & 4.94 & 1.34 \\
& Loss UD & 348 & 1 & 6 & 5.07 & 1.22 \\
& Gain LS D & 348 & 1 & 6 & 5.50 & .88 \\
& Gain LS UD & 348 & 1 & 6 & 5.44 & .94 \\
MF3 & Loss LS D & 348 & 1 & 6 & 4.87 & 1.56 \\
& Loss LS UD & 348 & 1 & 6 & 4.98 & 1.37 \\
& Gain MS D & 348 & 1 & 6 & 5.40 & .98 \\
& Gain MS UD & 348 & 1 & 6 & 5.33 & 1.06 \\
& Loss MS D & 348 & 1 & 6 & 5.02 & 1.41 \\
& Loss MS UD & 348 & 1 & 6 & 5.16 & 1.29 \\
\hline
\end{tabular}

Note. $\mathrm{LS}=$ Less severe; $\mathrm{MS}=$ More severe; $\mathrm{D}=$ desirable; $\mathrm{UD}=$ Undesirable.

Data were also examined for message outcome in the different conditions of severity. First, results showed no effect of desirable/ undesirable messages in the case of gain- and loss-framed messages that are less severe $\left(F(1,347)=1.67, p=.198, \eta_{\mathrm{p}}^{2}=.005\right),(F(1,347)=2.51$, $p=.114, \eta_{\mathrm{p}}^{2}=.007$, respectively). Second, the results also indicated that there is no main effect of desirable/undesirable message outcome for severe messages in the gain message-frame condition $(F(1,347)=2.36$, 
$\left.p=.126, \eta_{\mathrm{p}}^{2}=.007\right)$, but a main effect emerged for the loss messageframe $\left(F(1,347)=9.67, p=.002, \eta_{\mathrm{p}}{ }^{2}=.027\right)$, in which the participants were significantly more positive to loss message-frames that are more severe.

In this study, other factors, such as age, depression and anxiety levels, were also examined in relation to responses to the different conditions of message-frame. Results of these factors are reported in the subsequent sections.

\section{Age Effect on Message-frame Conditions}

Further analysis of the data was performed to explore the age effect on responses in different conditions of message frame. First, data were examined for gain/loss message frame. As predicted, older participants responded more positively to the messages (gain: $M=5.73, S D=.36$; loss: $M=5.50, S D=.87$ ) than younger adults (gain: $M=5.34, S D=.87$; loss: $M=4.90, S D=1.27$ ) and middle-aged participants (gain: $M=5.49, S D=.63$; loss: $M=5.07, S D=1.18$ ). These results are illustrated in Figure 1. These results were confirmed by Games-Howell Post hoc tests (see Appendix C). The multiple comparisons showed significant differences between older participants' responses to messages and young adults and middle-aged respondents $(p<.001 ; .01$, respectively). There was no significant difference in responses to the messages between young adults and middle-aged respondents $(p=.313)$.

To examine the data further within each age group, multiple pairwise comparisons were performed. The results of paired-samples $t$-test showed that young adults responded more positively to gain message frame $(M=5.34, S D=.87)$ relative to loss message frame $(M=4.90, S D=1.27), t(212)=7.2, p<.001, d=.40$. In this age group, no significant difference was observed in responses to less and more severe gain message frames $(t(212)=1.53, p=.128)$, but a significant difference was observed in the less and more severe loss message frame $(t(212)=-2.56, p=.011, d=.13)$, suggesting positivity to more severe loss framed messages. In terms of the message outcome, this age group responded more positively to the gain message frame that is desirable $(t(212)=2.24, p=.026, d=.13)$, but no statistically significant difference was found for the message outcome in the loss message frame. 
COVID-19 Health Communication: Key Moderators of Message...

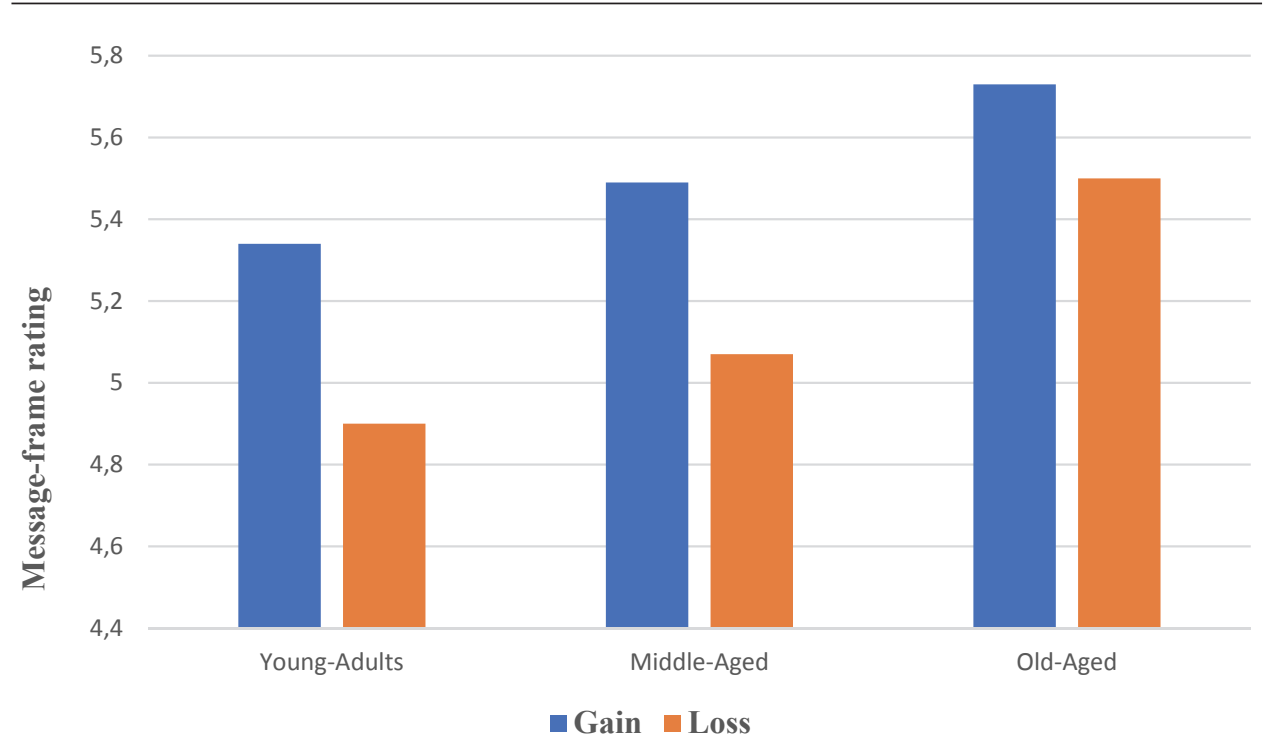

Figure 1. Age effect on responses to gain-loss message frame

Among the middle-aged group, the results of the $t$-test revealed statistically significant positive responses to gain message frame $(M=5.49, S D=.63)$ than to loss message frame $(M=5.07, S D=1.18)$, $t(95)=4.43, p<.001, d=.45$. In terms of message severity, the participants in this age group were more positive to less severe messages in the gain message frame $(t(95)=2.34, p=.021, d=.25)$ and to more severe messages in the loss message frame $(t(95)=-2.58$, $p=.011, d=.17)$. Concerning the message outcome, this age group responded more positively to the loss message-frame that is undesirable $(t(95)=-2.96, p<.01, d=.19)$, but no statistically significant difference was found for the message outcome in the gain message frame.

Interestingly, within the older age group, the pairwise comparisons showed no significant differences in responses to messages in all the message frame conditions. This indicates that the older participants were generally positive to messages regardless of severity (less severe, more severe) and desirability (desirable, undesirable).

\section{Relationship between Depression and Anxiety and Message- frame Conditions}

In addition to the age effect on responses to message frames, we examined whether there is a relationship between depression and anxiety 
COVID-19 Комунікачія з питань здоров'я: ключові модератори...

levels and participants' responses to different message frame conditions controlling for age. Descriptive analyses and reliability indices of scores on BDI (measure of depression) and STAI (measure of anxiety) are first reported in Table 3.

Table 3. Descriptive statistics and reliability indices of BDI and STAI tests scores

\begin{tabular}{llcccccc}
\hline \multirow{2}{*}{ Young-adults } & Test & $\boldsymbol{N}$ & $\boldsymbol{M i n}$ & $\boldsymbol{M a x}$ & $\boldsymbol{M}$ & $\boldsymbol{S D}$ & $\boldsymbol{\alpha}$ \\
& BDI & 212 & 0 & 43 & 12.21 & 8.54 & .86 \\
\multirow{3}{*}{ Middle-aged } & STAI & 212 & 21 & 79 & 46.37 & 13.47 & .93 \\
& BDI & 95 & 0 & 25 & 6.33 & 5.32 & .81 \\
Old-aged & STAI & 95 & 21 & 74 & 38.86 & 11.43 & .93 \\
& BDI & 41 & 0 & 23 & 7.44 & 6.48 & .85 \\
& STAI & 41 & 20 & 71 & 38.24 & 11.59 & .92 \\
\hline
\end{tabular}

Referring to the BDI scoring matrix, results of young adults showed, on average, a mild mode disturbance (within the scale of 1116), but middle-aged and old-aged appeared, on average, to be in the typical mode scale (within the scale of 1-10). Concerning anxiety level, the results of the STAI test indicated that young-adults, on average, fall within the high anxiety range (45-80) with a mean score of 46.37, and middle- and old-aged, on average, fall within the moderate anxiety scale (38-44) with mean scores of 38.86 and 38.24 , respectively. As shown in Table 3, the reliability indices of the items were high in both tests.

In order to examine if there is a relationship between depression and anxiety levels and perception of message frames, Spearman' rho correlation coefficients were computed for each age group. The results showed non-significant correlations of depression and anxiety levels with message frame perception in all conditions among young adults and middle-aged groups. However, among the older respondents, significant correlations were observed between depression level and 'loss' message-frame with undesirable outcome $(r=-.309, p<.05)$ and 'loss' message-frame that is less severe with undesirable outcome $(r=-.309, p<.05)$. Furthermore, anxiety level was found to correlate significantly with 'loss' message frame that is more severe $(r=-.330$, $p<.05)$. In a general sense, the results suggest that neither depression nor anxiety appear to affect the respondents' perception of health message frames. This conclusion is clearly supported by the results of 
young adults. Although this age group, as a cohort, appeared to fall within the high anxiety range, their anxiety level did not significantly correlate with their perception of message frame conditions.

\section{Discussion}

The results of the current study show that message framing had a significant influence on the emotional responses of the recipients of COVID-19 health messages. Participants responded generally more positively to gain- than to loss-framed messages. In other words, gainframed messages evoked more positive emotions than loss-framed messages. This result is in line with Mikels et al. (2016) claim that gain- and loss-framed messages engender different emotional responses. Thus, it can be recommended to phrase health messages along the gain frame rather than the loss frame if the recipient's affect is considered.

In addition to the message framing effect, the results of the present study highlight a clear influence for message severity and a moderate influence for the message outcome on the emotional responses of the participants. The participants responded more positively to gainframed messages including less severe measures than to gain-framed messages including more severe measures. A reverse pattern was noted with loss-framed messages as participants responded more positively when the measures were more severe than less severe. Hence, the severity of the precautionary/preventative measures seemed to influence the participants' affect. The participants responded more positively to gain-framed messages when the relevant preventative/precautionary measures were less severe while they were more positive to loss-framed messages when the measures were more severe. It is thus advisable to employ a gain frame in less severe contexts and a loss frame in more severe contexts.

The influence of the message outcome (in terms of desirability vs. undesirability) was less strong than the influence of the message's severity. The influence of the message outcome reached significance only with loss-framed messages. In loss-framed messages, the participants responded more positively to the messages with undesirable rather than desirable outcomes. It seems that the participants were more likely to accept loss-framed messages when they were related to more severe 
contexts and/or undesirable outcomes. Hence, the message outcome and severity are key moderators of message framing in the health domain.

Another important moderator of message framing is age. Older participants responded more positively to health messages, whether gain- or loss-framed, than younger and middle-aged participants in the current study. This result is partially aligned with the finding of Mikels et al.'s (2016) who found that older participants responded more positively to loss-framed messages than younger ones. However, both groups in Mikels et al.'s (2016) study had a similar response to gainframed messages. It is also important to note that the older participants' positivity to health messages in the present study was maintained regardless of the message framing severity or outcome. The situation was different with the younger and middle-aged participants whose emotional responses were influenced by the three variables. The two younger age groups responded more positively to gain- than loss-framed messages. The young adults expressed more positive emotions to more severe than less severe loss-framed messages and to gain-framed messages with desirable than undesirable outcomes. The message severity and outcome also intervened with the emotional responses of the middle-aged who responded more positively to less severe than more severe gain messages and to more severe than less severe loss messages. The middle aged were also more positive to undesirable than desirable outcomes in loss-framed messages.

The greater positivity of the older participants has been recurrently reported in the literature (for a review, see Mikels et al., 2014). This positivity has been repeatedly found in older adults' daily reports of positive and negative affect relative to those of the young (e.g., Carstensen et al., 2000; Charles, Reynolds \& Gatz, 2001). Research has also shown that older people respond with less reactivity to losses than younger people (e.g., Mikels \& Reed, 2009; SamanezLarkin et al., 2007) suggesting that loss frames have less impact on older than younger adults (Samanez-Larkin \& Knutson, 2014). It could be reasoned that, with age-related increases in loss, older adults may have more positive responses to loss-framed messages as they may feel better about loss prevention relative to the young (Mikels et al., 2016). Conversely, as losses are uncommon and unexpected in youth, younger adults may react more negatively to loss-framed messages relative to the old (Depping \& Freund, 2011). 
The older participants' greater positivity has also been interpreted in terms of a developmental shift in motivation that leads to differential processing of emotional information (Liu et al., 2019). According to the socioemotional selectivity theory (SST; Carstensen, Isaacowitz \& Charles, 1999), socio-emotional and information seeking goals change as a function of the perceived time left in life. As people get older and perceive that they have less time left in life, they tend to prioritize present-oriented and emotionally meaningful goals, avoid negative information and seek positive information to achieve well-being (Carstensen \& Mikels, 2005).

In addition to the above moderators of health message framing, the current study also examined the potential influence of depression and anxiety on participants' emotional responses to different framing of health messages. Against our expectations, neither depression nor anxiety levels of the participants had a major influence on their emotional responses to health messages. The two potential moderators showed minimal influence on the participants' emotional reaction, even among the young adults who exhibited a relatively higher level of anxiety. Past research indicates that it may be particularly difficult to persuade individuals who are depressed (Siegel, Lienemann \& Tan, 2015). It may be the case that on occasion, those who are depressed or experiencing quite a bit of anxiety may not be paying attention to messages in all cases - at least, not enough to produce an effect when it comes to message-framing research, as compared to those with low levels of anxiety (Leuck, 2017). It could be the case that in the present study, participants specifically with higher levels of anxiety and depression might not have attended to all of the messages in a way to actually demonstrate an effect that was distinct from those with low anxiety, with the current methods.

The current study presents some challenges to Rothman and Salovey's taxonomy (1997) which considers gain-framed messages as more efficient in promoting prevention behaviours whereas loss-framed messages will be more efficient in promoting detection behaviour. Although the present study focused only on preventative behaviours during the COVID-19 lockdown, the participants exhibited varying emotional responses to gain- and loss-framed messages and were influenced by a number of moderators, including age, message outcome and message severity. This explains why the new generation of framing 
research is looking beyond the categories of prevention versus detection and are seeking to specify the optimal conditions for using gain- and loss-framed messages (Latimer, Salovey \& Rothman, 2007).

\section{Conclusions}

One of the most popular persuasive strategies in health communication is message framing (Bruijn de, 2019) which generally stems from Rothman and Salovey's (1997) taxonomy of messages into gain-framed messages, which emphasize the positive consequences of action, and loss-framed messages, which highlight the negative consequences of inaction. For many years, research into message framing was concerned with this dichotomy, particularly with comparing the persuasive effectiveness of the two frames and their impact on behaviour change and decision making. Only recently has interest grown into examining the potential effect of different frames on the emotional responses of message recipients. This new direction is extremely important because health professionals need to encourage the public to comply with their advice without causing unnecessary anxiety among the message recipients. The current study aimed to contribute to this relatively new research direction through examining the emotional responses of Arabic-speaking Saudi nationals and residents of Saudi Arabia to different message frames during the COVID-19 lockdown. The study also examined the influence of a number of moderators, namely, message outcome, message severity, message recipient's age and message recipient's depression and anxiety levels.

The results of the current study showed that the participants generally responded more positively to gain-framed messages. A clear influence for message severity was noted as the participants responded more positively to gain-framed messages that are less severe and to loss-framed messages that are more severe. Some influence was also noted for message outcome within the loss-framed messages as the participants showed more positivity to loss-framed messages with undesirable outcomes. Additionally, age turned out to be a key moderator of message framing. Older people exhibited more positivity to all messages than the young and middle-aged adults. This positivity was maintained regardless of the message severity or outcome. The only 
COVID-19 Health Communication: Key Moderators of Message...

variables that did not seem to be impactful in this context were the message recipients' levels of depression and anxiety, neither of which affected the affective responses of the participants to the different health messages.

Based on the findings, we can make three recommendations. First, it is generally preferrable to use gain-framed than loss-framed messages when the recipient's affect is concerned. As for loss-framed messages, it is advisable to use them in more severe situations and with undesirable, rather than desirable outcomes. Loss-framed messages should be particularly avoided with younger adults since they generate highly negative emotional responses. Second, it is time to extend message framing research into exploring relevant moderators that influence the message framing effect and the different conditions under which differential effects for message framing show. Research that solely focuses on the dichotomy of gain- vs. loss-framed messages does not show the complexity of the real-life context. Finally, more research on the influence of message framing on the emotional responses of recipients is largely needed, particularly at times of health crises. At these times, people's anxiety levels are often high. Hence, health care professionals should avoid evoking more negative emotions with inappropriately phrased messages. It is also recommended to implement this relatively recent research direction among unexplored populations since most of the literature examines English-speaking populations.

\section{Acknowledgements}

The researchers thank Prince Sultan University for funding this research project through the Applied Linguistics Research Lab grant IBRP-CH-2020-6-1.

\section{References}

Bai, L., Rao, Q., Cai, Z., Lv, Y., Wu, T., Shi, Z., Sharma, M., Zhao, Y., \& Hou, X. (2019). Effects of goal-framed messages on mental health education among medical university students: Moderating role of personal involvement. Frontiers in Public Health, 7, 371. https://doi.org/10.3389/fpubh.2019.00371

Balbo, L. (2010). The message framing of health communications: How to elicit higher intention to get an annual pap test? Halshs-00534779. 
COVID-19 Комунікачія з питань здоров'я: ключові модератори...

Beck, A.T., Steer, R.A., \& Brown, G.K. (1996). Manual for the Beck Depression Inventory-II. San Antonio, TX; Psychological Corporation. https://doi.org/10.1037/ t00742-000

Bruijn de, G. (2019). To frame or not to frame? Effects of message framing and risk priming on mouth rinse use and intention in an adult population-based sample. Journal of Behavioural Medicine, 42, 300-314. https://doi.org/10.1007/s10865018-9972-1

Carstensen, L.L., \& Mikels, J.A. (2005). At the intersection of emotion and cognition: Aging and the positivity effect. Current Directions in Psychological Science, 14, 117-121. https://doi.org/10.1111/j.0963-7214.2005.00348.x

Carstensen, L.L., Isaacowitz, D.M., \& Charles, S.T. (1999). Taking time seriously: A theory of socioemotional selectivity. American Psychologist, 54, 165-181. https://doi.org/10.1037/0003-066X.54.3.165

Carstensen, L.L., Mikels, J.A., \& Mather, M. (2006). Aging and the intersection of cognition, motivation and emotion. In J. Birren, \& K.W. Schaie (Eds.), Handbook of the Psychology and Aging (6th ed., pp. 343-362). San Diego, CA: Academic Press. https://doi.org/10.1016/B9-78-012101-2/64950-0185

Carstensen, L.L., Pasupathi, M., Mayr, U., \& Nesselroade, J.R. (2000). Emotional experience in everyday life across the adult life span. Journal of Personality and Social Psychology, 79(4), 644-655. https://doi.org/10.1037/0022-3514.79.4.644

Charles, S.T., Reynolds, C.A., \& Gatz, M. (2001). Age-related differences and change in positive and negative affect over 23 years. Journal of Personality and Social Psychology, 80(1), 136-151. https://doi.org/10.1037/0022-3514.80.1.136

Depping, M.K., \& Freund, A.M. (2011). Normal aging and decision making: The role of motivation. Human Development, 54(6), 349-367. https://doi. org/10.1159/000334396

Elbert, S.P., \& Ots, P. (2018). Reading or listening to a gain- or loss-framed health message: Effects of message framing and communication mode in the context of fruit and vegetable intake. Journal of Health Communication, 23(6), 573-580. https://doi.org/10.1080/10810730.2018.1493059

Gallagher, K.M., \& Updegraff, J.A. (2012). Health message framing effects on attitudes, intentions, and behavior: A meta-analytic review. Annals of Behavioral Medicine, 43, 101-116. https://doi.org/10.1007/s12160-011-9308-7

Latimer, A.E., Salovey, P., \& Rothman, A.J. (2007). The effectiveness of gainframed messages for encouraging disease prevention behavior: Is all hope lost? Journal of Health Communication, 12(7), 645-649. https://doi. org/10.1080/10810730701619695

Liu, X., Shuster, M.M., Mikels, J.A., \& Stine-Morrow, E.A.L. (2019). Doing what makes you happy: Health message framing for younger and older adults. Experimental Aging Research, 45(4), 293-305. https://doi.org/10.1080/036107 3X.2019.1627491

Löckenhoff, C.E., \& Carstensen, L.L. (2007). Aging, emotion, and health-related decision strategies: Motivational manipulations can reduce age differences. Psychology and Aging, 22(1), 134-146. https://doi.org/10.1037/08827974.22.1.134

Lueck, J.A. (2017). Matching message design and depressed cognition: An exploration of attention patterns for gain- and loss-framed depression help-seeking messages. Journal of Health Communication, 22(7), 1-11. https://doi.org/10.1080/10810730 .2017 .1324538 
COVID-19 Health Communication: Key Moderators of Message...

Mays, D., \& Evans, W.D. (2017). The effects of gain-, loss-, and balanced-framed messages for preventing indoor tanning among young adult women. Journal of Health Communication, 22(7), 604-611. https://doi.org/10.1080/10810730.2017.1 332119

Mendeley Data (2021) - El-Dakhs, Dina, Altarriba, Jeanette, Masrai, Ahmed (2021), «Health Message Framing_Dataset», Mendeley Data, V1, http://dx.doi. org/10.17632/2v8k7kk9vt.1

Mikels, J.A., \& Reed, A.E. (2009). Monetary losses do not loom large in later life: Age differences in the framing effect. The Journals of Gerontology: Psychological Sciences and Social Sciences, 64B(4), 457-460. https://doi. org/10.1093/geronb/gbp043

Mikels, J.A., Reed, AE., Hardy, LA., \& Loeckenhoff, CE. (2014). Positive emotions across the adult life span. In M. Tugade, M. Shiota, \& L. Kirby (Eds.), Handbook of Positive Emotions. New York: Guilford Publications, Inc.

Mikels, J.A., Shuster, M.M., Thai, S.T., Smith-Ray, R., Waugh, C.E., Roth, K., Keilly, A., \& Stine-Morrow, E.A.L. (2016). Messages that matter: Age differences in affective responses to framed health messages. Psychological Aging, 31(4), 409-414. https://doi.org/10.1037/pag0000040

Notthoff, N., \& Carstensen, L.L. (2014). Positive messaging promotes walking in older adults. Psychology and Aging, 29(2), 329-341. https://doi.org/10.1037/a0036748

Rothman, A.J., \& Salovey, P. (1997). Shaping perceptions to motivate healthy behavior: The role of message framing. Psychological Bulletin, 121, 3-19. https://doi.org/10.1037/0033-2909.121.1.3

Samanez-Larkin, G.R., \& Knutson, B. (2014). Reward processing and risky decision making in the aging brain. In V.F. Reyna, \& V. Zayas (Eds.), The Neuroscience of Risky Decision Making (pp. 123-142). Washington DC: American Psychological Association. https://doi.org/10.1037/14322-006

Samanez-Larkin, G.R., Gibbs, S.B., Khanna, K., Nielsen, L., Carstensen, L.L., \& Knutson, B. (2007). Anticipation of monetary gain but not loss in healthy older adults. Nature Neuroscience, 10(6), 787-791. https://doi.org/10.1038/nn1894

Shamaskin, A.M., Mikels, J.A., \& Reed, A.E. (2010). Getting the message across: Age differences in the positive and negative framing of health care messages. Psychology and Aging, 25(3), 746-751. https://doi.org/10.1037/a0018431

Shen, L., \& Kollar, L.M.M. (2015). Testing moderators of message framing effect: A motivational approach. Communication Research, 42(5), 626-648. https://doi. org/10.1177/0093650213493924

Siegel, J.T., Lienemann, B.A., \& Tan, C.N. (2015). Influencing help-seeking among people with elevated depressive symptomatology: Mistargeting as a persuasive technique. Clinical Psychological Science, 3(2), 242-255. https://doi. org/10.1177/2167702614542846

Spielberger, C.D., Gorsuch, R.L., Lushene, R., Vagg, P.R., \& Jacobs, G.A. (1983). Manual for the State-Trait Anxiety Inventory. Palo Alto, CA: Consulting Psychologists Press.

Statista (2020). https://www.statista.com/statistics/806106/total-population-arab-league/

Stine-Morrow, E.A.L., \& Radvansky, G.A. (2017). Discourse processing and development through the adult lifespan. In M.F. Schober, D.N. Rapp, \& M.A. Britt (Eds.), The Routledge Handbook of Discourse Processing (2nd ed., pp. 247-268). New York, NY: Routledge. https://doi. org/10.4324/9781315687384-14 
Suka, M., Yamauchi, T., \& Yanagisawa, H. (2018). Comparing responses to differently framed and formatted persuasive messages to encourage help-seeking for depression in Japanese adults: A cross-sectional study with 2-month follow-up. BMJ Open, 8, e020823. https://doi.org/10.1136/bmjopen-2017-020823

Toll, B.A., O'Malley, S.S., Katulak, N.A., Wu, R., Dubin, J.A., Latimer, A., Meandzija, B., George, T.P., Jatlow, P., Cooney, J.L., \& Salovey, P. (2007). Comparing gain- and loss-framed messages for smoking cessation with sustainedrelease bypropion: A randomized controlled trial. Psychological Addictive Behaviors, 21(4), 534-544. https://doi.org/10.1037/0893-164X.21.4.534

Tversky, A., \& Kahneman, D. (1981). The framing of decisions and the psychology of choice. Science, 211, 453-458. https://doi.org/10.1126/science.7455683

Updegraff, J.A., Brick, C., Emanuel, A.S., Mintzer, R.E., \& Sherman, D.K. (2015). Message framing for oral health: Moderation by perceived susceptibility and motivational orientation in a diverse sample of Americans. Health Psychology, 34(1), 20-29. https://doi.org/10.1037/hea0000101

Wansink, B., \& Pope, L. (2014). When do gain-framed health messages work better than fear appeals. Nutrition Reviews, 73(1), 4-11. https://doi.org/10.1093/ nutrit/nuu010

\section{Appendix A - Beck's Depression Inventory}

This depression inventory can be self-scored. The scoring scale is at the end of the questionnaire.

1.

0 I do not feel sad.

1 I feel sad.

2 I am sad all the time and I can't snap out of it.

3 I am so sad all the time and I can't stand it.

2.

0 I am not particularly discouraged about the future.

1 I feel discouraged about the future.

2 I feel I have nothing to look forward to.

3 I feel the future is hopeless and that things cannot improve.

3.

0 I do not feel like a failure.

1 I feel I have failed more than the average person.

2 As I look back on my life, all I can see is a lot of failures.

3 I feel I am a complete failure as a person.

4.

0 I get as much satisfaction our of things as I used to.

1 I don't enjoy things the way I used to. 
COVID-19 Health Communication: Key Moderators of Message...

2 I don't get real satisfaction out of anything anymore.

3 I am dissatisfied or bored with everything.

5.

0 I don't feel particularly guilty.

1 I feel guilty a good part of the time.

2 I feel quite guilty most of the time.

3 I feel guilty all of the time.

6.

0 I don't feel I am being punished.

1 I feel I may be punished.

2 I expect ot be punished.

3 I feel I am being punished.

7.

0 I don't feel disappointed in myself.

1 I am disappointed in myself.

2 I am disgusted with myself.

3 I hate myself.

8.

0 I don't feel I am any worse than anybody else.

1 I am critical of myself for my weaknesses or mistakes.

2 I blame myself all the time for my faults.

3 I blame myself for everything bad that happens.

9.

0 I don't have any thoughts of killing myself.

1 I have thoughts of killing myself, but I would not carry them out.

2 I would like to kill myself.

3 I would kill myself if I had the chance.

10.

0 I don't cry any more than usual.

1 I cry more now than I used to.

2 I cry all the time now.

3 I used to be able to cry, but now I can't cry even thought I want to.

11.

0 I am no more irritated by things than I ever was.

1 I am slightly more irritated now than usual.

2 I am quite annoyed or irritated a good deal of the time.

3 I feel irritated all the time. 
12.

0 I have not lost interest in other people.

1 I am less interested in other people than I used to be.

2 I have lost most of my interest in other people.

3 I have lost all of my interest in other people.

13.

0 I make decisions about as well as I ever could.

1 I put off making decisions more than I used to.

2 I have greater difficulty in making decisions more than I sued to.

3 I can't make decisions at all anymore.

14.

0 I don't feel that I look any worse than I used to.

1 I am worried that I am looking old or unattractive.

2 I feel there are permanent changes in my appearance that make me look unattractive.

3 I believe that I look ugly.

15.

0 I can work about as well as before.

1 IT takes an extra effort to get started at doing something.

2 I have to push myself very hard to do anything.

3 I can't do any work at all.

16.

0 I can sleep as well as usual.

1 I don't sleep as well as usual.

2 I wake up 1-2 hours earlier than usual and find it hard to get back to sleep.

3 I wake up several hours earlier than I used to and cannot get back to sleep.

17.

0 I don't get more tired than usual.

1 I get tired more easily than I used to.

2 I get tired from doing almost anything.

3 I am too tired to do anything.

18.

0 My appetite is no worse than usual.

1 My appetite is not as good as it used to be.

2 MY appetite is much worse now.

3 I have no appetite at all anymore. 
COVID-19 Health Communication: Key Moderators of Message...

19.

0 I haven't lost much weight, if any, lately.

1 I have lost more than five pounds.

2 I have lost more than ten pounds.

3 I have lost more than fifteen pounds.

20.

0 I am no more worried about my health than usual.

1 I am worried about physical problems like aches, pains, upset stomach, or constipation.

2 I am very worried about physical problems and it's hard to think of much else.

3 I am so worried about my physical problems that I cannot think of anything else.

21.

0 I have not noticed any recent change in my interest in sex.

1 I am less interested in sex than I used to be.

2 I have almost no interest in sex.

3 I have lost interest in sex completely.

\section{INTERPRETING THE BECK DEPRESSION INVENTORY}

Now that you have completed the questionnaire, add up the score for each of the twenty-one questions by counting the number to the right of each question you marked. The highest possible total for the whole test would be sixty-three. This would mean you circled number three on all twenty-one questions. Since the lowest possible score for each question is zero, the lowest possible score for the test would be zero. This would mean you circles zero on each question. You can evaluate your depression according to the Table below.

Total Score

$1-10$

$11-16$

$17-20$

21-30

$31-40$

40
Levels of Depression

These ups and downs are considered normal Mild mood disturbance Borderline clinical depression Moderate depression Severe depression over Extreme depression 


\section{Appendix B State Anxiety Inventory for Adults}

A number of statements which people have used to describe themselves are given below. Read each statement and then blacken the appropriate circle to the right of the statement to indicate how you feel right now, that is, at this moment. There are no right or wrong answers. Do not spend too much time on any one statement but give the answer which seems to describe your present feelings best.

\begin{tabular}{|c|l|l|l|l|l|}
\hline 1 & I feel calm. & Not at all & Somewhat & Moderately so & Very much so \\
\hline 2 & I feel secure. & & & & \\
\hline 3 & I am tense. & & & & \\
\hline 4 & I feel strained. & & & & \\
\hline 5 & I feel at ease. & & & & \\
\hline 6 & I feel upset. & & & \\
\hline 7 & I am presently worrying & & & \\
\hline 8 & over possible misfortunes. & & & & \\
\hline 9 & I feel satisfied. & & & & \\
\hline 10 & I feel comfortable. & & & & \\
\hline 11 & I feel self-confident. & & & & \\
\hline 12 & I feel nervous. & & & & \\
\hline 13 & I am jittery. & & & & \\
\hline 14 & I feel indecisive. & & & & \\
\hline 15 & I am relaxed. & & & & \\
\hline 16 & I feel content. & & & & \\
\hline 17 & I am worried. & & & & \\
\hline 18 & I feel confused. & & & & \\
\hline 19 & I feel steady. & & & & \\
\hline 20 & I feel pleasant. & & & & \\
\hline
\end{tabular}




\title{
Appendix C
}

\section{Multiple Comparisons}

\begin{tabular}{|c|c|c|c|c|c|c|}
\hline \multicolumn{7}{|c|}{ Measure: Games-Howell } \\
\hline \multirow[b]{2}{*}{ (I) Age_Group } & \multirow{2}{*}{$\begin{array}{l}\text { (J) Age } \\
\text { Group }\end{array}$} & \multirow{2}{*}{$\begin{array}{l}\text { Mean } \\
\text { Difference (I-J) }\end{array}$} & \multirow{2}{*}{$\begin{array}{l}\text { Std. } \\
\text { Error }\end{array}$} & \multirow[b]{2}{*}{ Sig. } & \multicolumn{2}{|c|}{ 95\% Confidence Interval } \\
\hline & & & & & Lower Bound & Upper Bound \\
\hline \multirow[t]{2}{*}{ YoungAdults } & MiddleAged & -.159 & .1087 & .313 & -.415 & .098 \\
\hline & Old & $-.492 *$ & .1084 & .000 & -.750 & -.234 \\
\hline \multirow[t]{2}{*}{ MiddleAged } & YoungAdults & .159 & .1087 & .313 & -.098 & .415 \\
\hline & Old & $-.333 *$ & .1195 & .017 & -.617 & -.050 \\
\hline \multirow[t]{2}{*}{ Old } & YoungAdults & $.492 *$ & .1084 & .000 & .234 & .750 \\
\hline & MiddleAged & $.333 *$ & .1195 & .017 & .050 & .617 \\
\hline
\end{tabular}

*. The mean difference is significant at the .05 .

\begin{abstract}
АНОТАЦІЯ
Мета дослідження. Попередні дослідження структурованих моделей комунікації в системі здоров'язбереження часто фокусувались на ефективності повідомлень за критеріями впливу на поведінку і прийняття рішень. Значно менше уваги приділялося впливу структурування комунікацій на емочійні реакції реципієнтів. Цей знехтуваний аспект надзвичайно важливий, особливо в кризовий час, оскільки співробітники системи здоров'язбереження намагаються переконати суспільство притримуватися їхніх рекомендацій, не викликаючи при цьому зайвої зтурбованості. у цьому дослідженні вивчався вплив структурування повідомлень на емочійну среру арабомовних громадян і осіб, які проживають у Саудівській Аравії в період короновірусного карантину. Також досліджувався ступінь впливу повідомлень на респондентів та їхні тривожнодепресивні показники з урахуванням вікових характеристик.
\end{abstract}

Методики дослідження. Загалом протестовано 348 учасників, які представляють три вікові групи, за допомогою опитувальника депресії Бека (Beck et al., 1996) і опитувальника на реактивну й особистісну тривожність (Spielberger et al., 1983). Також учасники оцінювали за допомогою 6-бальної шкали Лайкерта рівень позитивності 48 епідеміологічних повідомлень у зв'язку з COVID-19.

Результати. Отримані результати продемонстрували сильний вплив структури повідомлень і віку на вираженість їхніх емоційних реакцій. Також був зафіксований деякий вплив цих факторів на результативність повідомлень.

Висновки. Рекомендується використовувати для населення здоров'язбережувальні комунікації, сформульовані на основі мотивації досягнення, щоб уникнути виникнення тривоги і забезпечити позитивний ефект. Особливо це рекомендується на молодих людей, емочійна сфера 
COVID-19 Комунікачія з питань здоров'я: ключові модератори...

яких легко вразлива для негативного впливу повідомлень, що спираються на мотивацію уникнення невдач. Такі повідомлення рекомендується використовувати в окремих складних ситуаціях, що потребують вказаного результата.

Ключові слова: здоров'язбережувальні комунікації, колективні емоції, тривога, структурування повідомлень, вік, комунікативний вплив, COVID-19.

Эль-Да Дина Абдель Салам, Альтарриба Жанетm \& Maсраи Ахмед. COVID-19 Коммуникация по вопросам здоровья: ключевые модераторы формирования речевых сообщений

\section{АННОТАЦИЯ}

Цель исследования. Предыдущие исследования структурированных моделей коммуникаций в системе здравоохранения часто фокусировались на эффективности сообщений по критериям влияния на поведение и принятия решений. Гораздо меньше внимания уделялось влиянию структурирования коммуникаций на эмоциональные реакции реципиентов. Этот пренебрегаемый аспект чрезвычайно важен, особенно в кризисное время, поскольку сотрудники системы здравоохранения стремятся убедить общественность придерживаться их рекомендаций, не вызывая при этом лишнего беспокойства. В текущем исследовании изучалось влияние структурирования сообщений на эмоциональную сферу арабоязычных граждан и лии, проживающих в Саудовской Аравии в период коронавирусного карантина. Также исследовались степень влияние сообщений на респондентов и их тревожно-депрессивные показатели с учетом возрастных характеристик.

Методики исследования. В общей сложности протестировано 348 участников, представляющих три возрастные группы, с помощью опросника депрессии Бека (Beck et al., 1996) и опросника на реактивную и личностную тревожность (Spielberger et al., 1983). Также участники оченивали с помощью 6-бальной шкалы Лайкерта уровень позитивности 48 эпидемиологических сообщений в связи с COVID-19.

Результаты. Полученные результаты продемонстрировали сильное влияние структуры сообщений и возраста реципиентов на выраженность их эмоциональных реакций. Также было зафиксировано некоторое влияние этих факторов на результативность сообщения.

Выводы. Рекомендуется использовать для населения здравоохранительные коммуникации, срормулированные на основе мотивации достижения, чтобы избежать возникновения беспокойства и обеспечить положительный эффект. Это особенно рекомендуется для молодых людей, эмоциональная сфера которых легко уязвима для негативного влияния сообщений, опирающихся на мотивацию избегания неудач. Такие сообщения рекомендуется использовать в отдельных сложных ситуациях, требующих указанного результата.

Ключевые слова: здравоохранительные коммуникации, коллективные эмоции, тревога, структурирование сообщений, возраст, коммуникативное влияние, COVID-19. 